\title{
The Role of the Curriculum in Teaching Tolerance among Students
}

\author{
Syifa Masna Raisalah \\ Department of Educational Management \\ Universitas Negeri Malang, Indonesia \\ syifaraisa@gmail.com
}

\author{
Mustiningsih \\ Department of Educational Management \\ Universitas Negeri Malang, Indonesia \\ mustiningsih.fip@um.ac.id
}

\author{
Muh. Adib Ahsan \\ Department of Educational Management \\ Universitas Negeri Malang, Indonesia \\ syifaraisa@gmail.com
}

\begin{abstract}
This study aims to understand and analyze multicultural curriculum theory in education, examine the discovery of problems related to teaching and field practice, and evaluate classroom teaching. The method used in this research is descriptive qualitative with the Principal of Primary School (SDN) Blimbing 3 Malang, Indonesia, as the research subject. The results of this study are multicultural curriculum has been ably applied decently in SDN Blimbing 3 Malang. Learning about tolerance has been successfully executed through the tolerance between friends at school. This success is supported by the principal's management in dealing with problems and curriculum compilation related to differences in students.
\end{abstract}

Keywords: education, curriculum, multicultural, management, student, principal

\section{INTRODUCTION}

The Indonesian nation consists of various kinds of people with varied background. Some of these backgrounds are race, religion, ethnicity, culture, education, and economy. These differences are then sought to be united through the motto: Bhinneka Tunggal Ika. This difference drives multiculturalism. To implement this motto, education in Indonesia creates a curriculum to teach tolerance and love for the diversity of our society.

Today, this tolerance has been eroded, which then triggers internal conflicts in Indonesia. Therefore, multicultural education needs to be taught and instilled early on, one of which is through teaching in elementary school. When a child is taught early on, and the teaching can be well embedded through curriculum management and teacher practice in the classroom, then the possibility of conflict in the future can be minimized. Therefore, this research was conducted to see the management of SDN Blimbing 3 in planning, organizing, leading, and supervising curriculum for multicultural communities.

Management is the process of organizing the work of members in an organization so that the activities in it can run effectively and efficiently. Management has four functional areas namely, planning, regulation, leadership, and supervision (Robbins and Coulter, 2007; Gunawan, 2017). The planning function aims to establish a strategy or method; the regulatory function, which is to set the work assignment (what is done and who does it); the leadership function is to direct and motivate all members; and the supervisory function, namely supervising activities so that members' tasks are completed according to plan.

Each curriculum is designed to improve school quality. Some curriculum periods used in Indonesia are the curriculum of $1945,1968,1975,1984,1994,2004$, and 2006. Concerning multiculturalism in Indonesia, the curriculum must also be adjusted accordingly. The overarching regulation is Government Regulation Number 55 Year 2007 concerning Religious Education and
Religious Education which requires education with the aim of uniting the Indonesian people to be harmonious and harmonious. Below is a breakdown of existing government regulations:

1. Religious education in formal education and equality education programs is at least conducted in the form of religious subjects or courses.

2. Every student in an education unit in all lines, levels, and types of education is entitled to receive religious education according to the religion they profess and to be taught by educators of the same religion.

3. Each education unit provides a place to hold religious education.

4. Educational units which cannot provide a place to hold religious education as referred to in paragraph 3 may cooperate with equal education units or providers of religious education in the community to organize religious education for students.

5. Each educational unit provides a place and opportunity for students to carry out worship based on the religious provisions adopted by the students.

6. Places for carrying out religious worship as referred to in paragraph (5) can be in the form of rooms in or around the environment of an education that can be used by students carrying out their worship.

7. Educational units which are characterized by specific religions are not obliged to build houses of worship for other religions other than those that are relevant to the religious characteristics of the relevant educational units.

\section{METHODS}

The method used in this research is descriptive qualitative that describes the situation with no author subjectivity, uses inductive analysis, and relates to a multicultural context. Primary data sources, namely data collected directly by researchers from the first source. In this study, the primary source taken by researchers was Ms. Suryatiningsih as the Principal of SDN Blimbing 3 Malang. 
Secondary data sources, data obtained not from the first source, but through the second source. This source is a primary source of supporting data. This study has several secondary data, namely school profiles and documentation. Data collection techniques used in research, namely: interviews, observation, and documentation.

\section{RESULT}

Curriculum for Multiculturalism in SDN Blimbing 3 Malang

The change of curriculum from KTSP to K13 still has an element of diversity. This was conveyed by the speakers that in the curriculum of students in the form of RPP, there is still a theme of tolerance between religious communities, and the teaching of religious education, both Islam, Christianity, Buddhism, Catholicism, and Hinduism. Until now, in Blimbing 3 Public Elementary School Malang, there are no students with Kong Hu Chu's belief.

In the teaching process, the teacher always reminds students of the importance of mutual respect and does not discriminate between humans or friends in their terms. Friends who have religions other than Islam, may not interfere when their Muslim friends are worshiping, and vice versa. For rigid data, the interviewees did not provide the number of students with religious classifications, but in general the majority of students in SDN Blimbing 3 Malang were Muslim.

Apart from going through the lesson plan, a striking difference is the physical difference in one of the students who just graduated last year. The student experienced an abnormality in his leg bones, so he could not stand up straight. Therefore, the student must be injected with booster medication in his legs every few hours to be able to stand and walk. For students, teachers teach not to make fun of their friends, but it is recommended to help.

\section{Implementation of Curriculum for Multiculturalism in SDN Blimbing 3 Malang}

In general, in SDN Blimbing 3 Malang the difference is not too large, whether in race, religion, ethnicity, or culture. Judging from the explanation above, there are religious and physical differences that are most visible in the condition of students at SDN Blimbing 3 Malang.

Nowadays, SDN Blimbing 3 Malang only provides a place of worship for Muslims, the mosque. Space for other religious services has not been provided, so that in its implementation, schools look for places or schools that can provide learning and worship together. Like students who are Hindu, they are combined with students at SD Bareng 3 to study together with Hindu teachers. The learning will be completed with a list of absences deposited from SDN Blimbing 3 to SDN Bareng 3.

Besides, for other religions such as Buddhism, the school provides direction to study in the Lawang area school that provides such learning. But unfortunately, based on existing reports, sometimes the teaching and learning process in Lawang is not done by because of the location being too far away. For this matter, the school can only appeal. This is because schools cannot provide each teacher which is hard to find and because there are very few students. So, to provide teachers is still being considered.

There is a special activity that becomes a means of implementing multiculturalism, namely during Friday prayers. On that day, all male students are required to worship in a congregation. For female students, everybody is collected in a room from any religion to be taught lady manner. This material covers how women should if they wear skirts, how to ride their motorbike skirts (whether polite or not), how to speak well, and so forth.

For students who have the physical differences above, the school is not too difficult when students are still in class one to three elementary schools. The problem is when the student is in grades 4 to 6 , because the class is located on the 2nd floor. In this case, the principal discusses with parents whether the child wants to be transferred to a school whose children have special needs or not, but the guardian of the student remains wants their children to go to SDN Blimbing 3. Therefore, informants offer solutions for parents to often come to recess and go home, to carry the child so they can go down and up. The form of tolerance taken by his friends is to help carry his friend when the child's parents do not come. They help the child to come down and sit in the schoolyard to see his friends playing or eating in the canteen.

\section{DISCUSSION}

Based on the findings above, there are several results of the analysis, namely: the management process, namely planning has been carried out by the principal of SDN Blimbing 3 Malang. Through the preparation of the change in SBC to Curriculum 13, continued with socialization to student guardians. The regulatory function is carried out through adjustments to the lesson plan and efforts to provide balanced learning opportunities. It can be seen that religion lesson is not only given to Muslim students, but also Hindu, Christian and Buddhist students. Although there is no place of worship other than the mosque, the school still looks for places of worship for non-Muslim students outside of school, and responsibly includes attendance. The curriculum itself is planning educational programs with the ultimate goal which is maximum education practices in Indonesia (Wiyono, 2018, Gunawan \& Benty, 2017)

The implementation of the curriculum provided to non-Muslim students following the Government Regulation Number 55 Year 2007 concerning Religious Education and Religious Education Chapter II Article 4. This indicates that there are efforts to comply with the rules of education in realizing a fair and wise Indonesian education. SDN Blimbing 3 Malang has been able to show harmony in education in schools, as stated in the Government Regulation above specifically article 5. The principal's supervisory function as a manager or supervisor at the school has been carried out through observations about the physical differences that are owned by one of the students (Gunawan, 2014; Kusumaningrum, et. al. 2017; Kusumaningrum, et. al. 2018). It can be seen from the discussion with the students' parents supported by motivation towards their peers. 


\section{CONCLUSION}

Based on the explanation above, it can be concluded that the multicultural curriculum has been able to be applied in the education unit of Blimbing 3 Malang Elementary School. Learning about tolerance has also been successful, it can be seen from tolerance between friends at school, through the princess program, playing together, and learning in class.

Researchers can see more broadly from the perspective of the principal as a policymaker in handling problems and compiling activities related to differences in student confidence. Cooperation, discussion with student guardians, planting mutual assistance with students, and joint activities are good forms of multicultural education.

\section{REFERENCE}

[1] Government Regulation Number 55 Year 2007 concerning Religious Education and Religious Education

[2] Gunawan, I. 2014. Pengaruh Supervisi Pengajaran dan Kemampuan Guru Mengelola Kelas terhadap Motivasi
Belajar Siswa. Ilmu Pendidikan Jurnal Kajian Teori dan Praktik Kependidikan, 41(1), 44-52.

[3] Gunawan, I. 2017. Indonesian Curriculum 2013 Instructional Management, Obstacles Faced by Teachers in Implementation and the Way Forward. Proceeding 3rd International Conference on Education and Training (3rd ICET) 2017, Theme: Global and Local Based Education and Training, Atlantis Press, 1(1), 56-63

[4] Gunawan, I., \& Benty, D. D. N. 2017. Manajemen Pendidikan: Suatu Pengantar Praktik. Bandung: Alfabeta.

[5] Kusumaningrum, D. E., Arifin, I., \& Gunawan, I. 2017. Pendampingan Pengembangan Perangkat Pembelajaran Berbasis Kurikulum 2013. ABDIMAS PEDAGOGI: Jurnal Ilmiah Pengabdian kepada Masyarakat, 1(1), 16-21.

[6] Kusumaningrum, D. E., Sumarsono, R. B., \& Gunawan, I. 2018. Teachers Empowerment of Pesantren-Based Junior High School East Java Province Indonesia. Journal of Social Sciences and Humanity Studies, 4(3), 29-33.

[7] Robbins, S., and Coulter, M. 2007. Management. Jakarta: PT Indeks.

[8] Wiyono, B. B. 2018. The Influence of School-Based Curriculum on the Learning Process and Students' Achievement. Advances in Social Science, Education and Humanities Research, 269, 